\title{
First report of freshwater atyid shrimp, Caridina formosae (Decapoda: Caridea) as a host of ectosymbiotic branchiobdellidan, Holtodrilus truncatus (Annelida, Citellata)
}

\author{
Rafał Maciaszek ${ }^{1, *}$, Aleksandra Jabłońska ${ }^{2}$, Sebastian Prati ${ }^{3}$ and Wiesław Świderek ${ }^{1}$ \\ ${ }^{1}$ Department of Animal Genetics and Conservation, Institute of Animal Sciences, Warsaw University of Life Sciences, ul. Ciszewskiego \\ 8, 02-786 Warsaw, Poland \\ ${ }^{2}$ Department of Invertebrate Zoology and Hydrobiology, University of Lodz, ul. Banacha 12/16, 90-237 Łodź, Poland \\ ${ }^{3}$ Department of Arctic and Marine Biology, Faculty of Biosciences, Fisheries and Economics, UiT The Arctic University of Norway, \\ Hansine Hansens veg 18, 9019 Tromsø, Norway
}

Received: 5 May 2020 / Accepted: 1 July 2020

\begin{abstract}
In recent years, ornamental shrimps gained increasing popularity in the aquarium trade. Unfortunately, they are potential vectors of epibionts, which may be unintentionally introduced to aquaria with imported shrimps. This contribution presents the first report of the occurrence of Holtodrilus truncatus on aquarium freshwater shrimp Caridina formosae. A total of 120 shrimp imported from Taiwan as aquarium pets were examined for the presence of epibionts. Holtodrilus truncatus occurred in $23.3 \%$ of shrimps. A total of $29.6 \%$ of crustaceans showed signs of damages as a result of $H$. truncatus activity. The shrimp is not common in the ornamental trade and is not subject to selective breeding. Therefore C. formosae populations available on the market, if not wild-caught, are most likely very similar to those occurring in Taiwanese natural water bodies, where $H$. truncatus occurs in Neocaridina shrimp. Neocaridina spp. are a known host for this epibiont, and transmission between species might occur in nature as well as in the aquarium trade were densities of animals are often high. The ability of $H$. truncatus to infect also highly invasive crayfish Procambarus clarkii, might also pose concern for regions where this crustacean is widespread. The actual lack of preventive measures for shrimp epibionts as well as confirmed releases of ornamental crustaceans into new aquatic ecosystems may result in further spread of H. truncatus, a potential new threat to native crustaceans and other epibionts.
\end{abstract}

Keywords: aquarium / alien species / epibiont / pet trade / Atyidae

Résumé - Premier signalement de la crevette atyide d'eau douce, Caridina formosae (Decapoda: Caridea) en tant qu'hôte du branchiobdelle ectosymbiotique, Holtodrilus truncatus (Annélide, Citellate). Ces dernières années, les crevettes ornementales ont gagné en popularité dans le commerce aquariophile. Malheureusement, elles sont des vecteurs potentiels d'épibiontes, qui peuvent être introduits involontairement dans les aquariums avec des crevettes importées. Cette contribution présente le premier rapport sur la présence de Holtodrilus truncatus sur les crevettes d'eau douce d'aquarium Caridina formosae. Au total, 120 crevettes importées de Taiwan comme animaux d'aquarium ont été examinées pour détecter la présence d'épibiontes. Holtodrilus truncatus était présent chez 23,3\% des crevettes. Au total, $29,6 \%$ des crustacés ont montré des signes de dommages résultant de l'activité de $H$. truncatus. La crevette n'est pas commune dans le commerce des plantes ornementales et n'est pas soumise à une reproduction sélective. Par conséquent, les populations de $C$. formosae disponibles sur le marché, si elles ne sont pas pêchées à l'état sauvage, sont très probablement très similaires à celles des plans d'eau naturels de Taïwan, où $H$. truncatus est présent dans les crevettes Neocaridina. Les Neocaridina spp. sont un hôte connu pour cet épibionte, et la transmission entre espèces pourrait se produire dans la nature ainsi que dans le commerce des aquariums où les densités d'animaux sont souvent élevées. La capacité de $H$. truncatus à infecter également l'écrevisse très envahissante Procambarus clarkii, pourrait également poser problème dans les régions où ce crustacé est très répandu. L'absence réelle de mesures préventives pour les épibiontes de crevettes ainsi que

\footnotetext{
*Corresponding author: rafal_maciaszek@sggw.pl
} 
les lâchers confirmés de crustacés ornementaux dans de nouveaux écosystèmes aquatiques pourraient entraîner une nouvelle propagation de $H$. truncatus, une nouvelle menace potentielle pour les crustacés indigènes et autres épibiontes.

Mots clés : aquarium / espèces exotiques / épibionte / commerce d'animaux de compagnie / Atyidae

\section{Introduction}

Ornamental aquaculture has a long history with millions of enthusiasts globally (Novák et al., 2020). Releases of aquarium crustaceans in novel aquatic environments by irresponsible owners and vendors have been reported worldwide (Chucholl, 2013; Patoka et al., 2014, 2017). The vast majority of reported cases involve the release of crayfish in urban and conurban waters (Patoka et al., 2016a). Freshwater shrimps, however, are also increasingly reported alien species in various new environments (Klotz et al., 2013; Jabłońska et al., 2018a; Weiperth et al., 2019a; Levitt-Barmats et al., 2019). Once released in a new environment, freshwater shrimps may compete with native species and possibly serve as potential vector of diseases (Klotz et al., 2013; Maciaszek et al., 2018; Levitt-Barmats et al., 2019). Moreover, relatively low levels of pathogen prevention and control as well as ineffectiveness of some related laws, in the aquarium trade, may further contribute to the global spread of undesirable hitchhikers (Patoka et al., 2016b; Patoka et al., 2018).

Freshwater shrimps are among the most common ornamental crustaceans kept in aquaria. Their often intense colouration is valuable to both breeders and hobbyists, and play a key role in their diffusion in the global aquarium trade (Maciaszek et al., 2018). The increasing popularity of these crustaceans has led to the development of many intensive breeding facilities, particularly in Taiwan. Shrimp farms often utilize artificial or seminatural ponds for the less expensive shrimps that are not subject to intensive selection, while a controlled environment, such as aquaria, is used for the finest and priciest selections (Maciaszek et al., 2018). However, not all ornamental shrimps are bred in captivity, as collection in the wild for some species is often more profitable (Calado, 2009; De Grave et al., 2015). Since colouration and price generally dictate how worth an animal is, cheap and poorly colored wildcaught species have higher chances of getting abandoned by their owners and are often used as live food in aquaculture as well as in indoor aquaria (Hung et al., 1993).

Caridina formosae (Hung et al., 1993) from the family Atyidae is a dwarf shrimp native to inland waters of Taiwan. This generally transparent olive, brown, or light pinkish-red species reaches up to $1.7 \mathrm{~cm}$ in body length (Hung et al., 1993). Thanks to its various colouration and characteristic dark spots, C. formosae is occasionally kept in, "so-called", biotope aquaria, aimed to recreate natural ecosystems in aquarium conditions. However, the species is not common in the aquarium trade, as its coloration is less attractive to breeders in comparison to certain other dwarf shrimps (Weiperth et al., 2019b; authors' observations). Therefore, C. formosae has not been a subject to selective or intensive breeding, in contrast to the often naturally coexisting Neocaridina davidi.

Unfortunately, aquarium shrimps, same as crayfish, are known to be vectors of several diseases and pests, which in some cases can have detrimental effect. For instance, the invasive North American crayfish, Procambarus clarkii and certain other decapods, have been reported as non-symptomatic carriers of the crayfish plague, a disease that is lethal to crayfish of non-North American origin (Svoboda et al., 2014; Putra et al., 2018). However, health issues of intensively farmed low-cost shrimps are often overlooked by the breeders (Maciaszek et al., 2018). This has largely contributed to the presence of other, undesirable species, such as epibionts in the breeding ponds. In some cases, unchecked imported shrimps, become the source of the accidental introductions of epibionts in aquaria and seminatural pond farms (Patoka et al., 2016a; Maciaszek et al., 2018) as well as within natural water bodies (Niwa et al., 2005; Ohtaka et al., 2012).

Branchiobdellidans are leech-like obligate epibionts of crustaceans, mainly crayfish (Gelder and Williams, 2015). Most of them were historically endemic; however, humanmediated transportation of crayfish and shrimps, unintentionally translocated these associated organisms alongside into new locations (Niwa and Ohtaka, 2006; Ohtaka et al., 2012; Gelder and Williams, 2015). They are opportunistic omnivores, hunting for plankton and algae, but also feed on detritus as well as host hemolymph. Among the branchiobdellidans, Holtodrilus truncatus is, at present, the only member reported in Atyidae shrimp of South-East Asia (Gelder and Williams, 2015; Ohtaka et al., 2015). To date, H. truncatus has been found in Neocaridina spp. in Japan, Korea, China, and Taiwan (Niwa and Ohtaka, 2006; Ohtaka et al., 2012, Ohtaka et al., 2015; Ahn and Min, 2016), Caridina pseudodenticulata, in Taiwan (Ohtaka and Chen 2010), C. leucostica, C. multidentata, C. rubella, C. rapaensis, C. typus, and Paratya compressa in Japan (Fujita et al., 2010; Tanaka et al., 2016).

To our knowledge, H. truncatus has never been reported in C. formosae. Moreover, this epibiont has not yet been reported among imported shrimps destined to the aquarium hobby. To date, the only reported epibiont in C. formosae is the microsporidium Triwangia caridinae (Wang et al., 2013). With the present paper, we contribute with a new addition to the list of epibionts of $C$. formosae, providing the first confirmed evidence of $H$. truncatus occurring on that species. This is also the first report of the presence of this epibiont in imported shrimps destined to the aquarium hobby.

\section{Material and methods}

\subsection{Epibiont detection and observation}

We examined a total of 120 Caridina formosae adults (total length $\sim 1.6 \mathrm{~cm}$ ) from a shipment of aquarium fauna imported from Taipei, Taiwan, to Warsaw, Poland, in March 2019. Shrimps were transported in four aquarium bags containing 30 individuals each. All individuals were identified using morphological descriptions provided by Hung et al. (1993). No ovigerous female was present. The sample included 74 


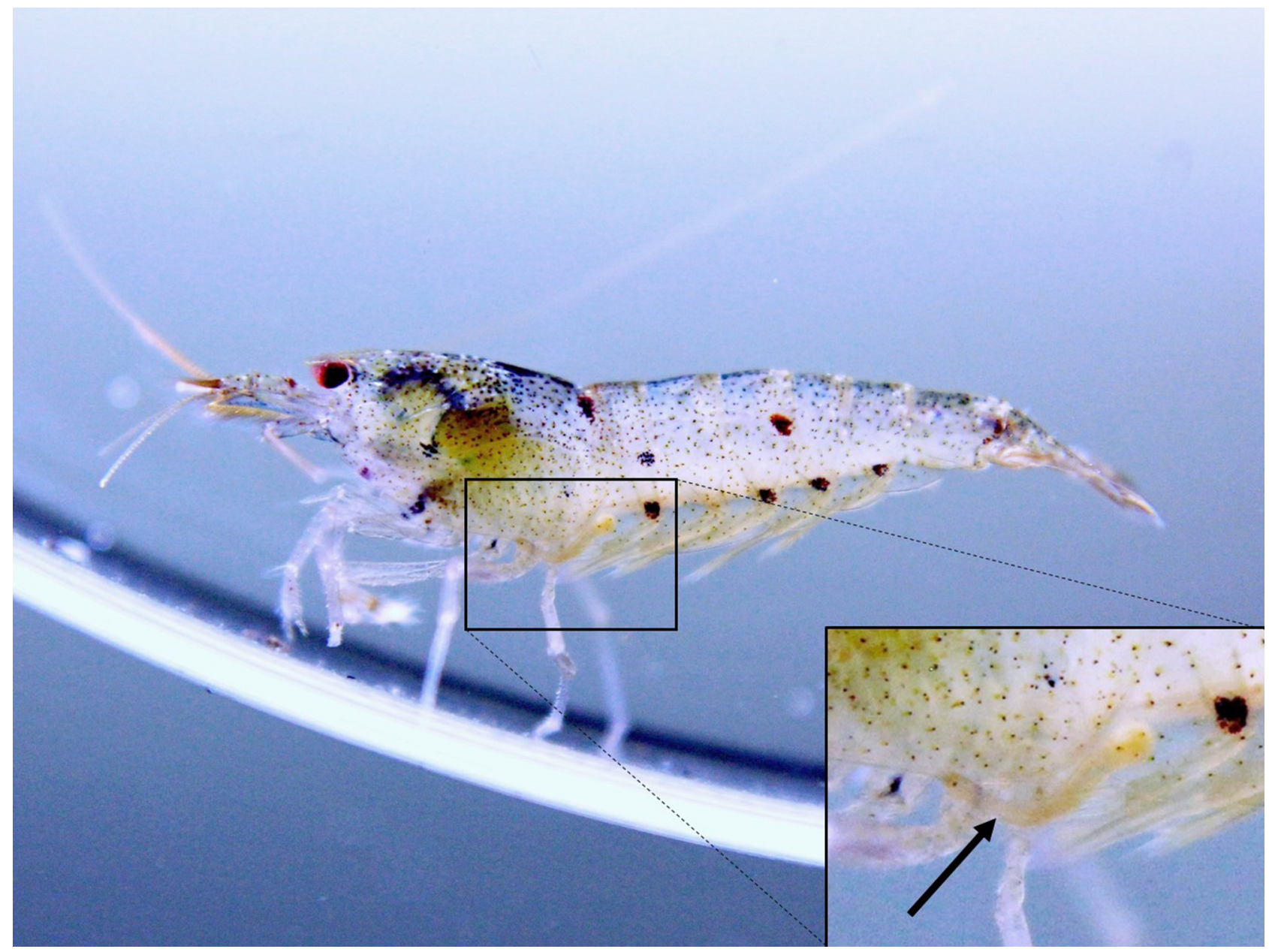

Fig. 1. Adult Holtodrilus truncatus (black arrow) penetrating C. formosae body (pereiopodal area).

females, 38 males, and 8 individuals with no evident sexual dimorphism. After arrival, shrimps were acclimatized in four separate aquaria of $20 \times 10 \times 10 \mathrm{~cm}$ filled with the water of the relative transport bag $(\sim 1.51)$ and illuminated using $6500 \mathrm{~K} 21 \mathrm{~W}$ fluorescent lamp. After 10 hours, each shrimp was captured and analyzed for epibionts presence or traces of activity in four different microhabitats defined according to Maciaszek et al. (2018) as rostrum area, gills, pereiopods area, as well as pleopods and abdomen area. Preliminary observations were carried out directly in each aquarium by secluding each individual shrimp with a petri dish pushed against the inner part of the wall (Fig. 1). To constrain movement of epibionts among different shrimp individuals, infected shrimps were separated for further inspection under the microscope, Leica DM50000B (Leica Camera AG, Wetzlar, Germany). Isolated epibiont individuals were counted, photographed with Canon DR- $\mathrm{E}^{\wedge} \mathrm{DC}$-Coupler EOS 5D (Canon Inc., Tokio, Japan) and identified using available literature (Ohtaka and Chen, 2010; Ahn and Min, 2016) as well as DNA barcoded.

\subsection{Molecular analyses}

Two individuals of episymbiotic branchiobdellidans were DNA barcoded with cytochrome C oxidase subunit I (COI) marker. The whole bodies were used for DNA extraction with the phenol-chloroform method (Hillis et al., 1996). The polymerase chain reaction (PCR) was conducted according to the protocol provided by Hou et al. (2007) with the primer pair HCOJJ/LCOJJ (Astrin and Stuben, 2008). PCR products were then purified using Exonuclease I and FastAP alkaline phosphatase (Werle et al., 1994) and subsequently sequenced by Macrogen Inc., Korea. Obtained sequences were verified by BLAST search (Altschul et al., 1990) and deposited in BOLD Systems (Ratnasingham and Hebert, 2007) as well as in the GenBank database (Benson et al., 2005). Haplotypes were detected in DnaSP software (Librado and Rozas, 2009). The phylogenetic tree was built with Maximum Likelihood method in MEGA 7.0 using substitution model and bootstrap test performed on 1000 replicates (Kumar et al., 2016). The sequence of $H$. truncatus was retrieved from GenBank database and used for the comparison (accession number KX683299, deposited by Ahn and Min (2016). Additionally, sequences of Xironogiton kittikasi deposited in GenBank by Williams et al. (2013) (accession number JQ821632) and Branchiobdella pentadonta deposited in GenBank by Šarić et al. (2018) with accession number KY775124, were used as outgroups. 

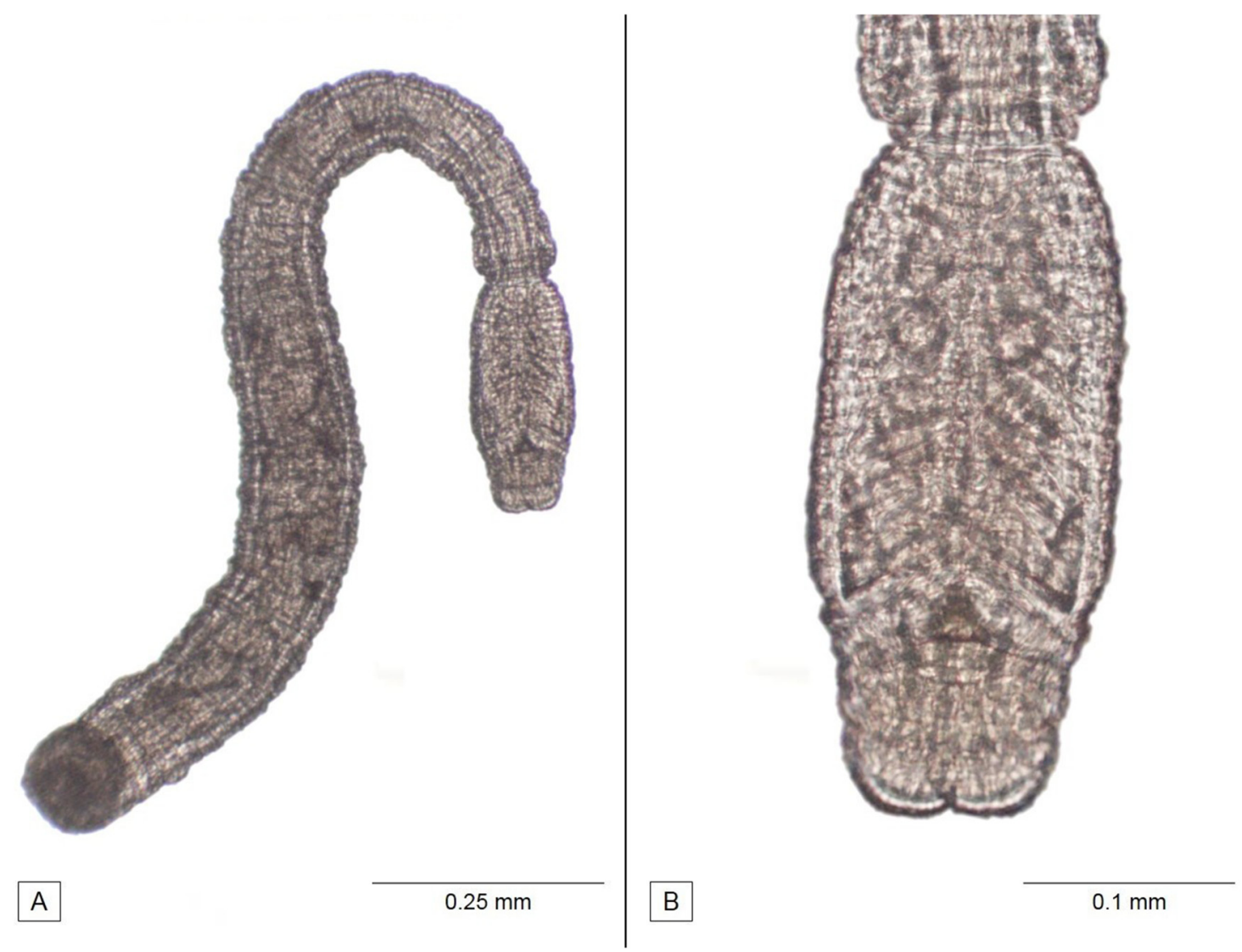

Fig. 2. (A) Whole-body image of Holtodrilus truncatus adult isolated from Caridina formosae and (B) close-up image of H. truncatus head.

\subsection{Statistical analyses}

Descriptive and statistical analyses were conducted in $\mathrm{R} 3.6$ (R Core Team, 2020). To investigate differences in H. truncatus load between $C$. formosae sex, the quantitative parameters prevalence, intensity, and mean intensity were analyzed. Eight individuals without evident sexual dimorphism were not infected and excluded from statistical analysis. Prevalence is the proportion of infected hosts in the host sample and expressed in percentage. The prevalence of $H$. truncatus in the host sample was compared between male and female hosts using Fisher's exact test. Intensity is the number of parasite individuals in an infected host individual. Mean intensity is the average number of parasite individuals found in all infected hosts (non-infected hosts were excluded). A 95\% confidence interval for mean intensity was obtained by using the bias-corrected and accelerated $(\mathrm{BCa})$ bootstrap with 10,000 replications. To asses microhabitat preferences of $H$. truncatus among female and male shrimps, we used generalized linear models (GLM) with binomial distribution for prevalence and negative binomial distribution for intensity followed by ANOVA. Correlations among damaged areas, prevalence, and intensity were analyzed with Spearman's rank correlation coefficient.

\section{Results}

A total of 122 adult branchiobdellidans and two cocoons were found among the shrimp sample and identified as H. truncatus (Fig. 2, Tab. 1). Representatives of this epibiont species had a brownish-transparent body ranging from 1.5 to $2.5 \mathrm{~mm}$ in length when alive. Peristomial lobe and dorsal segmental appendage absent (Fig. 2A). The head measured between 0.15 and $0.24 \mathrm{~mm}$ in width and was always broader than the first segment (Fig. 2B). The dorsal and ventral jaws were similar in size $(\sim 30 \mu \mathrm{m}$ in width) and shape: orangishbrown, triangular, with a large median tooth and three pairs of smaller lateral teeth [3-1-3/3-1-3], sometimes a single lateral tooth was missing. Cocoons were transparent, $\sim 0.5 \mathrm{~mm}$ in height, ovoid in shape, with a peduncle cemented onto the gill surface. Molecular analysis revealed that both individuals belong to one haplotype (Fig. 3).

In all examined $C$. formosae, $23.3 \%$ were infected by at least one $H$. truncatus individual. Overall, the mean intensity of $H$. truncatus was higher in females than males, while males had higher epibiont prevalence (Tab. 1). However, differences in prevalence between male and female shrimps were not significant (Fisher's exact test, $p=0.498$ ). At the shrimp population level, $H$. truncatus showed marked microhabitat preferences with $44.3 \%$ occurrence in the pereiopods area, $22.1 \%$ in the rostrum area, $21.3 \%$ in the pleopods and abdomen area, and $12.3 \%$ in the gills. Similar to what observed in the combined sample, $H$. truncatus specimens were more frequent in the pereiopods area of both females and males of C. formosae ( $43.5 \%$ and $46.7 \%$ respectively). However, with the exception of gills area, the occurrence of $H$. truncatus across other microhabitats differed among male and female shrimps. In females, $29.3 \%$ of $H$. truncatus occurred in rostral area, and $14.1 \%$ in pleopodal and abdominal area, whereas in 
males, the epibiont was absent in rostral area and was more frequent in pleopodal and abdominal area (43.3\%). Differences in microhabitat utilization among males and females of C. formosae were also apparent in the prevalence and mean intensity of $H$. truncatus (Tab. 2). The prevalence of

Table 1. Prevalence and mean intensity of Holtodrilus truncatus in the Caridina formosae sample.

\begin{tabular}{llll}
\hline & \multicolumn{3}{c}{ C. formosae } \\
\cline { 2 - 4 } & All & Females & Males \\
\hline Sample size & 112 & 74 & 38 \\
Prevalence (\%) & 23.3 & 23.0 & 28.9 \\
Mean intensity (95\% CI) & $4.4(3.3-6.1)$ & $5.4(3.8-7.9)$ & $2.7(1.9-3.5)$ \\
\hline
\end{tabular}

H. truncatus was higher in pereiopodal area of females and pleopodal and abdominal area of males. Pereiopodal area of females also had the highest mean intensity of $H$. truncatus, while in males, the highest mean intensity was observed on pereiopods. In males, the prevalence of $H$. truncatus significantly differed among microhabitats (ANOVA, $\chi^{2}$ $(3)=14.672, p=0.002$ ), but not in females (ANOVA, $\chi^{2}$ $(3)=0.109, p=0.991)$. In contrast, differences in mean intensity among microhabitats were significant for females of $C$. formosae (ANOVA, $\chi^{2}(3)=15.369, p=0.001$ ) but not for males (ANOVA, $\chi^{2}(2)=4.1173, p=0.1276$ ). Moreover, two females harbored one cocoon each in their gills chambers.

\section{Discussion}

Here we provide additional evidence on the occurrence of H. truncatus in atyid shrimp, as well as the first report of this

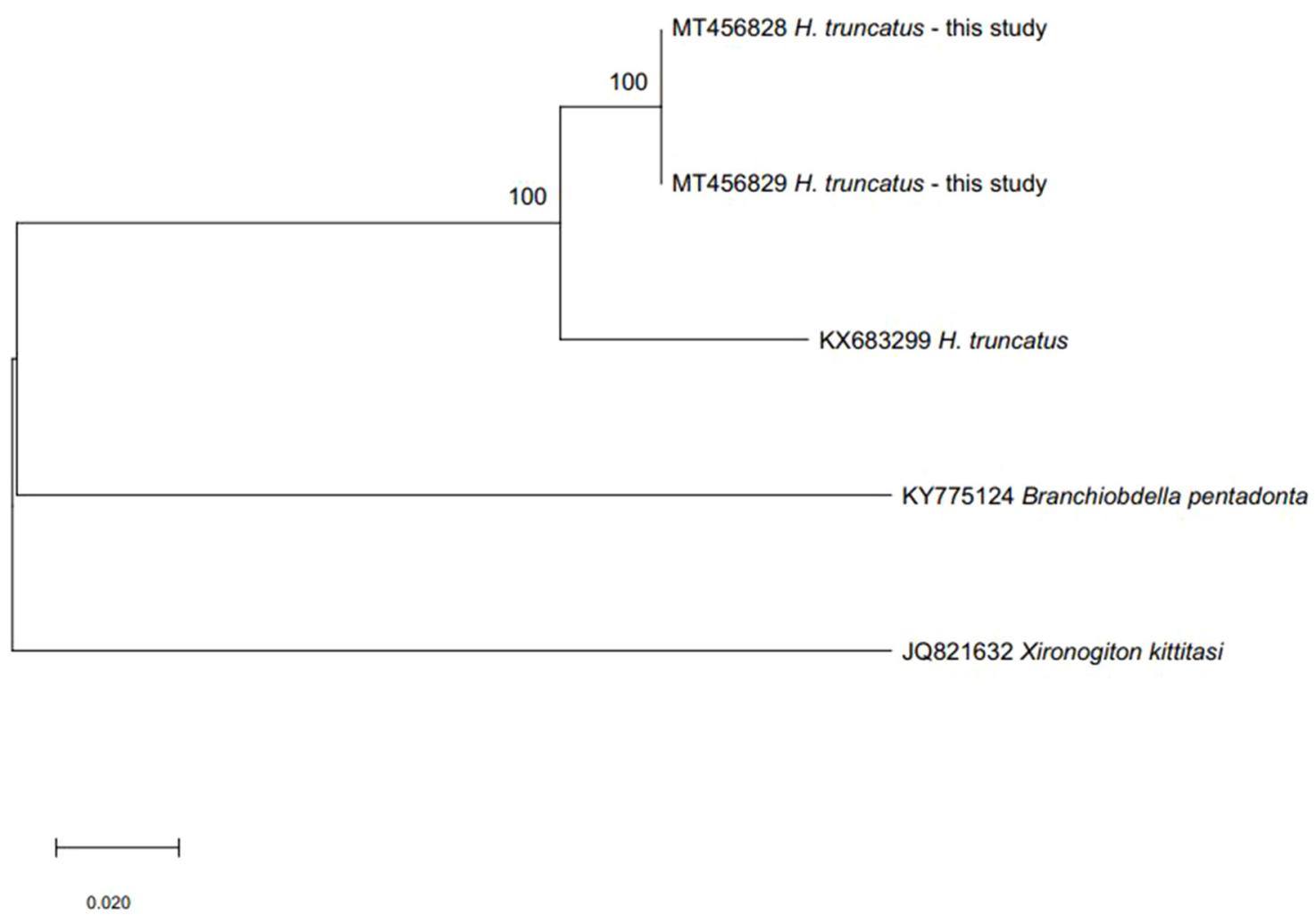

Fig. 3. Maximum-likelihood tree for examined Holtodrilus truncatus and GenBank-stored sequences.

Table 2. Prevalence and mean intensity of Holtodrilus truncatus.

\begin{tabular}{llllll}
\hline Microhabitat & \multicolumn{3}{c}{ Females $(n=74)$} & & \multicolumn{2}{c}{ Males $(n=38)$} \\
\cline { 2 - 3 } \cline { 5 - 6 } & Prevalence & Intensity $(95 \%$ confidence interval) & & Prevalence & Intensity $(95 \%$ confidence interval) \\
\hline Rostrum & $10.8 \%$ & $3.38(2.25-4.25)$ & - & - \\
Gills & $10.8 \%$ & $1.5(1.12-1.75)$ & & $2.6 \%$ & 3 \\
Pereiopods & $12.2 \%$ & $4.44(2.67-7.78)$ & $10.5 \%$ & $3.5(1-4.5)$ \\
Pleopods and abdomen & $10.8 \%$ & $1.62(1.12-2)$ & $21.1 \%$ & $1.62(1.12-1.88)$ \\
Entire body & $23 \%$ & $5.41(3.76-7.88)$ & $28.9 \%$ & $2.73(1.91-3.45)$ \\
\hline
\end{tabular}


branchiobdellidan in $C$. formosae. Moreover, the presence of cocoons in the shrimp gills indicated that the reproduction of $H$. truncatus occurs in $C$. formosae, proving that this shrimp species is a suitable host and, consequently, a potential vector for this epibiont. In this study, the overall majority of $H$. truncatus were found in pereiopodal area, suggesting at first glance a microhabitat preference toward this area. Contrary to what observed in female $C$. formosae, $H$. truncatus displayed a preference for pleopodal and abdominal area of males. Microhabitat preference toward pereiopodal area as well as pleopodal and abdominal area is also in agreement with the finding of Niwa et al. (2014), who identified the preferred attachment location in Neocaridina spp. between the fifth pereiopod and the first pleopod. The choice of this area may not be casual, as it facilitates access to the gill chamber, carapace, and eggs when ovigerous females are present (Niwa et al., 2014).

In accordance with the observation of Ohtaka et al. (2012) on Neocaridina spp. we detected damages in gills as well as pleopodal and abdominal area of $C$. formosae. Females more likely presented damages in both areas, suggesting that the activity of $H$. truncatus might be higher in them than in males. Accordingly, cocoons were only found on C. formosae females. At a similar body length, females generally have a larger surface area than males, due to a more robust body, thus offering higher opportunity for movement and attachment. This might explain why females showed damages in multiple locations, harbored cocoons, and overall had higher intensities of $H$. truncatus inhabitation. However, it is not excluded that other factors such as differences in molting frequency between male and female shrimps, if present, may also play a role in $H$. truncatus infestations. The high mobility of the epibiont can explain the absence of correlation between prevalence and intensity of $H$. truncatus in these areas. According to the effects caused by other shrimp epibionts, having similar microhabitat preferences such as Scutariellidae (Platyhelminthes: Rhabdocoela) members (Ohtaka et al., 2015), it is not excluded that the occurrence of $H$. truncatus on aquarium shrimps may have a detrimental effect on host fitness. Weakened shrimp may also have lower reproduction frequency and less intense colouration resulting in loss of income for breeders. However, without rigorous investigations on the nature of the relationships between $H$. truncatus and C. formosae, the potential adverse effect on shrimp fitness remains speculative (Gelder and Williams, 2015).

In Taiwan, $C$. formosae coexists with other freshwater shrimp species such as $N$. davidi on which $H$. truncatus has also been reported (Ohtaka et al., 2015), suggesting that this epibiont may potentially migrate among different crustacean species. Migrations of $H$. truncatus among different species of crustaceans, including the red swamp crayfish $P$. clarkii, proved to occur under experimental conditions (Niwa et al., 2014). We, therefore, can not exclude that under favorable conditions, this might happen as well in the natural environment. It is not clear if our sample of C. formosae, was breed in captivity or was wild-caught; therefore, we can not identify if our sample was in touch with $H$. truncatus in the wild, in the shrimp farm or at the wholesaler facility. Although preventive measures such as quarantine and bath in a saline solution (Tanaka et al., 2016) might prevent the spread of $H$. truncatus, these are scarcely implemented by shrimp farms and wholesale facilities. If unnoticed, the usually high density of shrimp in farm and wholesaler facilities might facilitate the spread of $H$. truncatus among different species of shrimp and, eventually, crayfish that finally end up in private aquaria. Moreover, as shrimp females are bigger and more colourful than males, imported ornamental freshwater shrimps typically display a skewed sex ratio toward females, which according to our results, harbor a higher burden of $H$. truncatus and cocoons, potentially enhancing the spread of this epibiont to other decapod crustaceans.

Branchiobdellidan representatives are often endemic; however, human-mediated transportation of crustaceans may enhance their distribution range through releases of infected individuals into new locations. In certain areas, competitive interactions with alien branchiobdellidans have already impacted native species (James et al., 2017). Moreover, the ability of $H$. truncatus to infect different crustacean species, including the crayfish Procambarus clarkii, one of the most invasive species in the world (Gherardi and Acquistapace, 2007; Johović et al., 2020), might potentially enhance the spread of this epibiont.

Among European crustaceans, branchiobdellidans are found only on crayfish (Longshaw, 2011; Skelton et al., 2013; Subchev, 2014). However, H. truncatus may be transmitted to native atyid shrimp species (Tanaka et al., 2016), including Atyaephyra sp., as well as Dugastella valentina, which is an endangered species (Christodoulou et al., 2016; Jabłońska et al., 2018b). Limited information is available on the influence of $H$. truncatus on its hosts (Tanaka et al., 2016), and the occurrence of this epibiont species may have both positive as well as negative effect on populations of European crustaceans in case of its accidental introductions to natural water bodies. Although cohabitation between branchiobdellidans and other epibionts such as the European members of the family Scutariellidae which also use shrimps as specific hosts might occur (Matjašič, 1990; Ohtaka et al., 2015; Pešić et al., 2018), interactions among H. truncatus and other native epibionts are also unpredictable.

To sum up, the occurrence of $H$. truncatus in imported ornamental shrimps creates opportunities for its global spread via the aquarium trade. Due to its small size, and transparent colouration, the presence of $H$. truncatus may go unnoticed, particularly in shrimp with intensive pigmentation. Its spread might be facilitated by possible migration to other more popular crustacean species kept by aquarium hobbyists and accidentally spread to native and other highly invasive species once ornamental crustaceans are released in the natural environment. We, therefore, urge for more control over this epibiont to limit its diffusion. Preventive measures such as quarantine and bath in a saline solution are recommended.

Acknowledgments. This work was supported by the Warsaw University of Life Sciences under Grant No. 505-10-072500Q00390-99.

\section{References}

Ahn DH, Min GS. 2016. First report of the branchiobdellidan Holtodrilus truncatus (Annelida: Clitellata) found on the freshwater atyid shrimp Neocaridina sp. from Korea. J Species Res 5: $459-462$. 
Altschul SF, Gish W, Miller W, Myers EW, Lipman DJ. 1990. Basic local alignment search tool. J Mol Biol 215: 403-410.

Astrin JJ, Stuben PE. 2008. Phylogeny in cryptic weevils: molecules, morphology and new genera of western Palaearctic Cryptorhynchinae (Coleoptera: Curculionidae). Invertebr Syst 22: 503-522.

Benson DA, Karsch-Mizrachi I, Lipman DJ, Ostell J, Wheeler DL. 2005. GenBank. Nucleic Acids Res 33: 34-38.

Calado R. 2009. Marine ornamental shrimp: biology, aquaculture and conservation. Lisbon: John Wiley and Sons, 475-476.

Christodoulou M, Anastasiadou C, Jugovic J, Tzomos T. 2016. Freshwater shrimps (Atyidae, Palaemonidae, Typhlocarididae) in the Broader Mediterranean Region: distribution, life strategies, threats, conservation challenges and taxonomic issues. In Kawai T, Cumberlidge N, eds. A global overview of the conservation of freshwater decapod crustaceans. Cham: Springer, 199-236.

Chucholl C. 2013. Invaders for sale: trade and determinants of introduction of ornamental freshwater crayfish. Biol Invasions 15: 125-141.

De Grave S, Smith KG, Adeler NA et al. 2015. Dead shrimp blues: A global assessment of extinction risk in freshwater shrimps (Crustacea: Decapoda: Caridea). PLoS ONE 10: 3.

Fujita Y, Kawahara T, Niwa N, Shokita RS. 2010. First record of Holtodrilus truncatus (Liang, 1963) (Annelida: Clitellata: Branchiobdellidae) from the Ryukyu Islands. Biol Mag Okinawa 48: 25-33 (In Japanese with English abstract).

Gelder SR, Williams BW. 2015 Citelliata: Branchiobdellida. In Thorp JH, Rogers DH, eds. Thorp and Covich's Freshwater Invertebrates. Amsterdam: Elsevier, 551-563.

Gherardi F, Acquistapace P. 2007. Invasive crayfish in Europe: the impact of Procambarus clarkii on the littoral community of a Mediterranean lake. Freshw Biol 52: 1249-1259.

Hillis DM, Moritz C, Mable BK. 1996. Molecular systematic. Second ed. Sunderland, MA: Sinauer Associates.

Hou Z, Fu J, Li S. 2007. A molecular phylogeny of the genus Gammarus (Crustacea: Amphipoda) based on mitochondrial and nuclear gene sequences. Mol Phylogenet Evol 2: 596-611.

Hung MS, Chan TY, Yu HP. 1993. Atyid shrimps (Decapoda: Caridea) of Taiwan, with descriptions of three new species. J Crustacean Biol 13: 481-503.

Jabłońska A, Mamos T, Gruszka P, Szlauer-Łukaszewska A, Grabowski M. 2018a. First record and DNA barcodes of the aquarium shrimp, Neocaridina davidi, in Central Europe from thermally polluted River Oder canal, Poland. Knowl Manag Aquat Ecosyst 419: 14.

Jabłońska A, Mamos T, Zawal A, Grabowski M. 2018b. Morphological and molecular evidence for a new shrimp species, Atyaephyra vladoi sp. nov. (Decapoda, Atyidae) in the ancient Skadar Lake system, Balkan Peninsula-its evolutionary relationships and demographic history. Zool Anzr 275: 66-79.

James J, Davidson KE, Hunt R, Cable J. 2017. Assessing the invasion potential of non-native branchiobdellidans: experimental studies of survival, reproduction and competition. Knowl Manag Aquat Ecosyst 418: 35.

Johović I, Verrucchi C, Inghilesi AF, Scapini F, Tricarico E. 2020. Managing the invasive crayfish Procambarus clarkii: Is manual sterilisation the solution. Freshw Biol 65: 621-631.

Klotz W, Miesen FW, Hüllen S, Herder F. 2013. Two Asian freshwater shrimp species found in a thermally polluted stream system in North Rhine-Westphalia, Germany. Aquat Invasions 8: 333-339.

Kumar S, Stecher G, Tamura K. 2016. MEGA7: molecular evolutionary genetics analysis version 7.0 for bigger datasets. Mol Biol Evol 33: 1870-1874.
Levitt-Barmats YA, Yanai Z, Cohen TM, Shenkar N. 2019. Lifehistory traits and ecological characteristics of the ornamental shrimp Neocaridina denticulata (De Haan, 1844), recently introduced into the freshwater systems of Israel. Aquat Invasions 14: 684-702.

Librado P, Rozas J. 2009. DnaSP v5: a software for comprehensive analysis of DNA polymorphism data. Bioinformatics 25: $1451-1452$

Longshaw M. 2011. Diseases of crayfish: a review. J Invert Pathol 106: $54-70$.

Maciaszek R, Kamaszewski M, Strużyński W, Łapa P. 2018. Epibionts of ornamental freshwater shrimps bred in Taiwan. Ann Warsaw Univ of Life Sci SGGW. Anim Sci 57: 133-142.

Matjašič J. 1990. Monography of the family Scutariellidae (Turbellaria, Temnocephalidea). Ljubljana: Academia Scientiarum et Atrium Slovenica, 45-91.

Niwa N, Ohtomi J, Ohtaka A, Gelder SR. 2005. The first record of the ectosymbiotic branchiobdellidan Holtodrilus truncatus (Annelida, Clitellata) and on the freshwater shrimp Neocaridina denticulata denticulata (Caridea, Atyidae) in Japan. Fish Sci 71: 685-687.

Niwa N, Ohtaka A. 2006. Accidental introduction of symbionts with imported freshwater shrimps. In Koike F, Clout MN, Kawamichi M, De Poorter M, Iwatsuki K, eds. Assessment and control of biological invasion risks. Kyoto, Japan/Gland, Switzerland and Shoukadoh Book Sellers/IUCN, 182-186.

Niwa N, Archdale MV, Matsuoka T, Kawamoto A, Nishiyama H. 2014. Microhabitat distribution and behaviour of Branchiobdellidan Holtodrilus truncatus found on the freshwater shrimp Neocaridina spp. from the Sugo River, Japan. Cent Eur J Biol 9: 80-85.

Novák J, Kalous L, Patoka J. 2020. Modern ornamental aquaculture in Europe: early history of freshwater fish imports. Rev Aquacult 2020: https://doi.org/10.1111/raq. 12421

Ohtaka A, Chen RT. 2010. New records of a branchiobdellidan and four microdrile oligochaetes (Annelida: Clitellata) from inland waters of Taiwan. Taiwan J Biodivers 12: 97-110.

Ohtaka A, Gelder SR, Nishino M, Ikeda M, Toyama H, Cui YD, He XB, Wang HZ, Chen RB, Wang ZY. 2012. Distributions of two ectosymbionts, branchiobdellidans (Annelida: Clitellata) and scutariellids (Platyhelminthes: "Turbellaria": Temnocephalida), on atyid shrimp (Arthropoda: Crustacea) in southeast China. J Nat Hist 46: 1547-1556.

Ohtaka A, Gelder SR, Yamato S, Chen RT, Nishino M. 2015. Cohabitation of Ectosymbiotic Branchiobdellida (Annelida, Clitellata) and Scutarielloidae (Platyhelminthes, Rhabditophora, Temnocephalida) on Atyid Shrimps in Taiwan. Taiwan J Biodivers 17: 253-262.

Patoka J, Petrtýl M, Kalous L. 2014. Garden ponds as potential introduction pathway of ornamental crayfish. Knowl Manag Aquat Ecosyst 414: 13.

Patoka J, Bláha M, Devetter M, Rylková K, Čadková Z, Kalous L. 2016a. Aquarium hitchhikers: attached commensals imported with freshwater shrimps via the pet trade. Biol Invasions 18: 457-461.

Patoka J, Buřič M, Kolář V, et al. 2016b. Predictions of marbled crayfish establishment in conurbations fulfilled: evidences from the Czech Republic. Biologia 71: 1380-1385.

Patoka J, Bláha M, Kalous L, Kouba A. 2017. Irresponsible vendors: Non-native, invasive and threatened animals offered for garden pond stocking. Aquat Conserv 27: 692-697.

Patoka J, Magalhães ALB, Kouba A, Faulkes Z, Jerikho R, Vitule JRS. 2018. Invasive aquatic pets: failed policies increase risks of harmful invasions. Biodivers Conserv 27: 3037-3046. 
Pešić V, Gadawski P, Gligorović B, Glöer P, Grabowski M, Kovács T, Murányi D, Płóciennik M, Šundić D. 2018. The diversity of the Zoobenthos communities of the Lake Skadar/Shkodra basin. In Pešić V, Karaman G, Kostianoy AG. eds. The Skadar/Shkodra Lake Environment. Cham: Springer, 255-293.

Putra MD, Bláha M, Wardiatno Y, et al. 2018. Procambarus clarkii (Girard, 1852) and crayfish plague as new threats for biodiversity in Indonesia. Aquat Conserv 28: 1434-1440.

$\mathrm{R}$ Core Team. 2020. A language and environment for statistical computing. Vienna, Austria: R Foundation for statistical computing. Retrieved from https://www.R-project.org

Ratnasingham S, Hebert PDN, 2007. BOLD: the Barcode of Life data system www.barcodinglife.org). Mol Ecol Notes 7: 355-364.

Šarić I, Klobučar G, Podnar M, Štambuk A, Maguire I. 2018. Molecular phylogeny of branchiobdellidans (Annelida : Clitellata) and their host-epibiont association with Austropotamobius freshwater crayfish, Invertebr Syst 32: 55-68.

Skelton J, Farrell KJ, Creed RP, Williams BW, Ames C, Helms BS, Stoekel J, Brown BL. 2013. Servants, scoundrels, and hitchhikers: current understanding of the complex interactions between crayfish and their ectosymbiotic worms (Branchiobdellida). Freshw Sci 32: $1345-1357$.

Subchev M. 2014. The genus Branchiobdella Odier, 1823 (Annelida, Clitellata, Branchiobdellida): a review of its European species. Acta Zool Bulg 66: 5-20.
Svoboda J, Strand DA, Vrålstad T, et al. 2014. The crayfish plague pathogen can infect freshwater-inhabiting crabs. Freshw Biol 59:918-929.

Tanaka K, Wada K, Hamasaki K. 2016. Distribution of Holtodrilus truncatus, a Branchiobdellidan ectosymbiotic on atyid shrimps in the Kii Peninsula, Western Japan, with reference to salinity tolerance and host preference. Zool Sci 33: 154-161.

Wang TC, Nai YS, Wang CY, Solter LF, Hsu HC, Wang CH, Lo CF. 2013. A new microsporidium, Triwangia caridinae gen. nov., sp. nov. parasitizing fresh water shrimp, Caridina formosae (Decapoda: Atyidae) in Taiwan. J Invertebr Pathol 112: 281-293.

Weiperth A, Gábris V, Danyik T, Farkas A, Kuř́ková P, Kouba A, Patoka J. 2019a. Occurrence of non-native red cherry shrimp in European temperate waterbodies: a case study from Hungary. Knowl Manag Aquat Ecosyst 420: 9.

Weiperth A, Gál B, Kuříková P, Langrová I, Kouba A, Patoka J. 2019b. Risk assessment of pet-traded decapod crustaceans in Hungary with evidence of Cherax quadricarinatus (von Martens, 1868 ) in the wild. North-West J Zool 15: 42-47.

Werle E, Schneider C, Renner M, Völker M, Fiehn W. 1994. Convenient single-step, one tube purification of PCR products for direct sequencing. Nucleic Acids Res 22: 4354-4355.

Williams BW, Gelder SR, Proctor HC, Coltman DW. 2013. Molecular phylogeny of North American branchiobdellida (Annelida: Clitellata). Mol Phylogenet Evol 66: 30-42.

Cite this article as: Maciaszek R, Jabłońska A, Prati S, Świderek W. 2020. First report of freshwater atyid shrimp, Caridina formosae (Decapoda: Caridea) as a host of ectosymbiotic branchiobdellidan, Holtodrilus truncatus (Annelida, Citellata). Knowl. Manag. Aquat. Ecosyst., 421, 33. 